\title{
DESIGN CONCEPT FOR GREEN PUBLIC SPACE IN KAMPONG
}

\author{
Sukmo D. WIDHARTO ${ }^{a}$, Nurfahmi MUCHLIS ${ }^{b}$, Sigit H. LAKSONO ${ }^{c}$, \\ Purwanita SETIJANTI ${ }^{d}$ \\ E-mails: ${ }^{a}$ sukmoduto@gmail.com (corresponding author); bfahmi.muchlis@gmail.com; \\ csigitarci@yahoo.com; dpsetijanti@arch.its.ac.id \\ Received 09 January 2014; accepted 15 March 2015
}

\begin{abstract}
The lack of environmentally friendly development in major city has made the public space in kampongs (or kampung) neglected. The need of a green community space to interact is increasingly scarce. The remaining areas that can be used as an outdoor space are alleys and pathways inside kampong. Public space should then be adaptive in order to meet the demands in a diverse society, thus emerged a design concept of adaptive public space using the capabilities of bamboo to deliver adaptive spaces with a limited range of conditions in its design, construction and usability. Bamboo has been frequently used by the people because of its sustainable characteristic. The method used in this study is the case study method. Qualitative data were collected through observations and interviews resulted in the analysis of existing conditions then formulized as a design criteria. Design method uses the concept of programming which is to formulate the mission, goals and performance requirements to create a concept. The drawn conclusion is that the alleys inside the kampong can be used as a public space by applying adaptive design principles. The use of bamboo in design is an appropriate solution based on its construction and material properties.
\end{abstract}

Keywords: adaptive, bamboo, green concept, kampong, public space.

\section{Introduction}

"Kampong" community is a group of people living in urban areas that are maintaining a socio-cultural pattern of behaviour and habits in their area of residence. As a result of maintaining the culture of 'kampong' in their daily lives, the physical order of the kampong area tend to be not well-organized. On the other hand the urban development continues to bring significant influence on the conditions in the surrounding area. Added development as a result of population growth has made a higher density in some particular area. Public space becomes scarce and green space switching its function. This density leaves little room for socializing. Children do not have enough places to play. Alley way in the kampongs became a collective gathering area or activity for everyone.

The kampongs in Surabaya has had its own peculiar character and characteristics. Judging from the problems as stated above, one of Surabaya government efforts to create a healthy kampong is to hold a program called "Surabaya Bersinar Green and Clean
(Green, clean, and shining Surabaya)" (Hijau 2013). The purpose of this program is to stimulate community kampongs to compete in making their kampong more beautiful and innovative. Unfortunately not all people of the community are able to grasp the meaning of this program. So far there are some kampongs which only made a small green space to fill their small yard. Those conditions are still less than ideal to fulfil a vegetation ecological function. An attempt to integrate the needs of society constrained by land and vegetation to form an outer space is needed.

Limited land and the need of green and public spaces in the kampong are the problems that are the focus in this study. Discussion questions and objectives that arise are: how to present a public space that is ideal for people in kampong with a limited land, how to integrate the needs of green spaces in the kampong area, and what is the design concept for an adaptive public space and for green space in order to create the better condition for kampong communities. 


\section{Theory study}

\section{Public spaces}

Public space is a public place where people perform routine and functional activities binding of a community, both in the normal routines of daily life, or in a periodic celebration (Carr et al. 1992). In this study the concept of the public space is more focused on an open space for the community. According to the form of activity that occurs in open space, Lynch (1960) categorized it into two, namely the field (square) and path (street). Open space, either in the form field or the corridor, is one of the elements of urban design which is very important in controlling the quality of the ecological and social environment (Shirvani 1985).

\section{Adaptive architecture}

In architecture, an adaptive design can be interpreted as an adaptable design, the design that pays attention to the surroundings by utilizing a variety of things in their environment. This effort is associated with integrating the things that are flexible, interactive and responsive with the use of architectural elements (Kronenburg 2007). Adaptive design can be understood as interventions that are able to blend with the environment.

\section{Bamboo material}

The application of bamboo in architecture can be very diverse in building elements. Bamboo can be used as a substitute for the support structure or steel reinforcement in concrete structures. Bamboo also is elastic, sturdy, and able to withstand the compressive load, tensile, shear, and bending. In Indonesia bamboo is a plant that is easy to find, and relatively fast growing. To qualify the construction requirement a bamboo needs to grow for 3-7 years, this is much faster than wood (10-30 years). Its strength is also better than that of wood (Xiao et al. 2008).

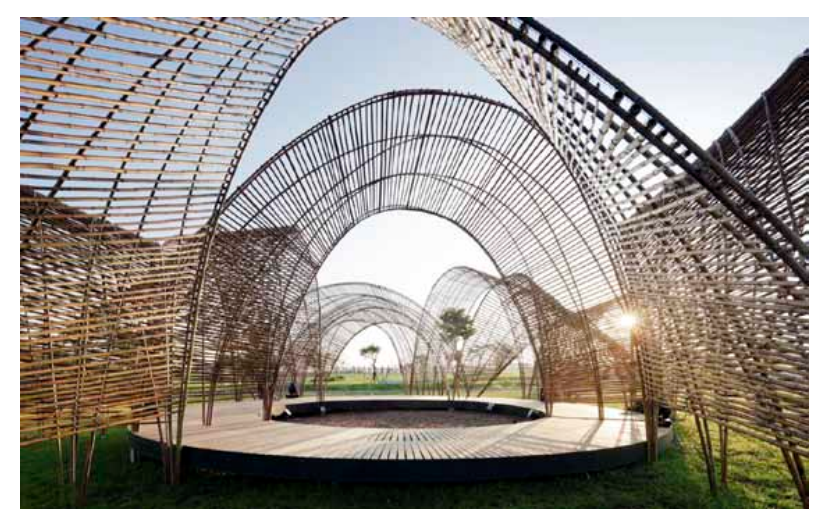

Fig. 1. Forest Pavilion by nArchitect (source: http://www. archdaily.com/165393/forest-pavilion-narchitects/na_twn_ ib_1365/)
As for some of the characteristics of bamboo as a material chosen in this design includes:

- Bamboo has good physical and mechanical properties. The trunk has a structure that is concentrated on the surface of the outer wall, tough, but flexible, easy to cut and shape. Bamboo has elastic fibres, has an optimum tensile loads to withstand press, shear, and buckling. Some species of bamboo has a tensile strength of $480 \mathrm{MPa}$, equivalent to $12 \mathrm{ton} / \mathrm{m}^{2}$, exceeds the tensile strength of steel quality of only $370 \mathrm{MPa}$.

- Relatively inexpensive compared to other building materials because it is a local material that grows in many places in Indonesia.

- Are non-polluting materials because it is organic, recyclable.

- It has a life cycle of less than 6 years. In ten years the bamboo plants may be harvested up to three times. As a building material, bamboo has been used by many architects and designers, especially because of its sustainable properties. Bamboo architecture may well seem to be some sort of exotic form of field. Following are the sustainable examples of organic bamboo architecture and field study. These examples are limited to the use of bamboo in a semi-permanent or temporary architecture.

Forest Pavilion (Fig. 1) serves as a shaded meeting and performance space for visitors to the $\mathrm{Da}$ Nong $\mathrm{Da}$ Fu Forest and Ecopark in Hualien province, Taiwan. It is also designed to be used as a small outdoor theatre. The pavilion is comprised of eleven vaults built with freshly cut green bamboo.

Another example for bamboo as a sustainable building material is showed in the design concept of temporary houses in response to the 7.9 earthquake that struck China in May 2008. Named Folded Bamboo Houses (Fig. 2), the concept utilizes a system of bamboo poles that are preassembled into rigid geometric

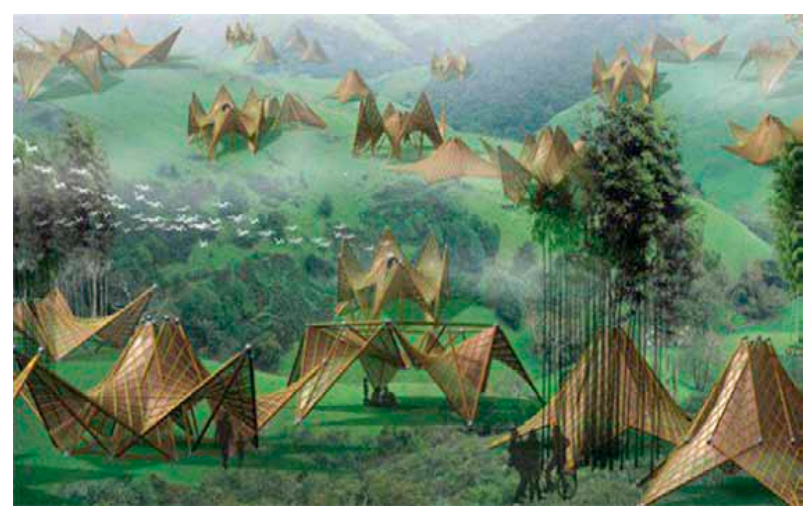

Fig. 2. Folded Bamboo House by Ming Tang (Basulto 2008) 


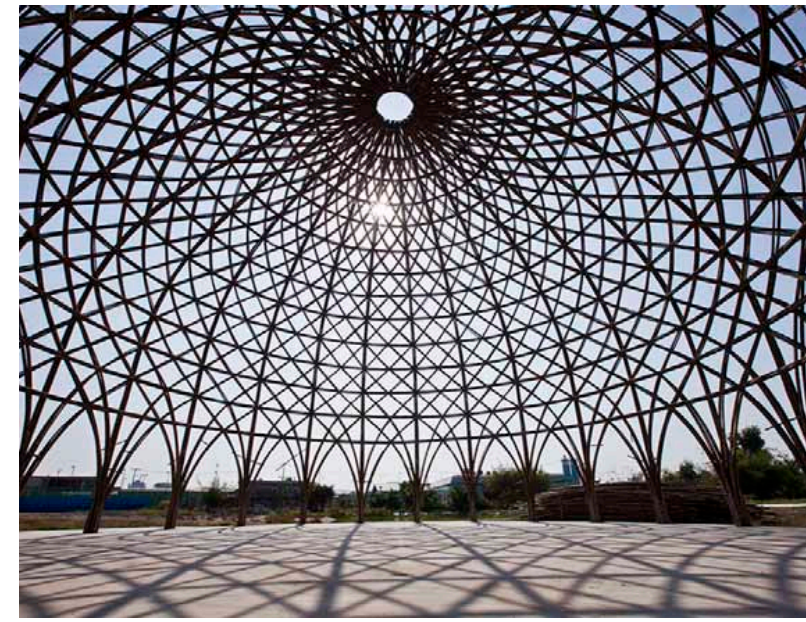

Fig. 3. Bamboo Domes by Vo Trong Nghia Architects (Frearson 2014)

shapes. The geometry of the forms provides integrity to each structure, allowing a range of lightweight modular structures to be quickly preassembled in workshops and transported to the site.

The third example is Bamboo Domes by Vo Trong Nghia Architects in Vietnam. These domes are used as a part of a community space in Diamond Island Community Hall to provide flexible events spaces for local residents.

In those three examples of bamboo structures, we can see that the designers harness the potential and characteristics of bamboo in their design. Depending on the use in building - as a main structure or as the membrane that wraps it - the bamboo stalk is not just used as it is but in some cases they are split and bent to achieve interesting and artistic form.

\section{Methodology}

This study uses a case study of Kampung Karangrejo Sawah RT IV, District of Wonokromo, Surabaya. Qualitative data were collected through direct observation as well as from interviews in the field. The result is an analysis of existing conditions that will be realized as design criteria. Design method used is the method of programming by Duerk (1993) by formulating the mission, goals and performance requirements to create a design concept.

\section{Problems in the study area}

Problems in the study area that will be discussed next are issues that relate directly to the physical condition of environment and community activities in the mentioned kampong.

\section{Physical sector}

\section{Road and alleys}

According to Local Government Legislation No. 13, 1980 (Undang-Undang Republik Indonesia 1980), a road is a land infrastructure including complementary building (shelter) and equipment intended for transportation. Road (or alleys) found in Kampung Karangrejo Sawah are in a good condition and its material is made from pavement blocks. The width of the alleys inside the kampong is 3 meters, but for the road heading to the kampong has a width that varies between 4 meters to 6 meters.

The alley with a width of 3 meters does not allow two four-wheeled vehicles to pass each other. That is why a one-way street system is applied in which fourwheeler motorists can only go through the alley from east to west. The road network in the kampong also supports this so rarely found system in which two or more vehicles may stuck in the middle of the alley inside the kampong.

There are two alleys in one RT (Rukun Tetangga Neighbourhood Association). Alleys in RT 4 that are the focus in this paper are Alley I and II. The pavement for the alley is a relief from the Surabaya city government awarded to RT 4 to RT 6. RT 7 did not receive help in the form of pavements for the road because the road conditions are still good and road is wider than the kampong road in RT 4 to RT 6.

Unfortunately, the sidewalks were not done by first destroying the existing asphalt, but they are directly stacked with sand and pavement as seen in Figure 4. This could potentially cause flooding or water clogging problems in near future because the soil lost its water absorbing property. The addition of height from this pavement also reduces the gap between the road level and the floor level of the houses, potentially causing the pool of rain water which gets inside the house in a heavy rain.

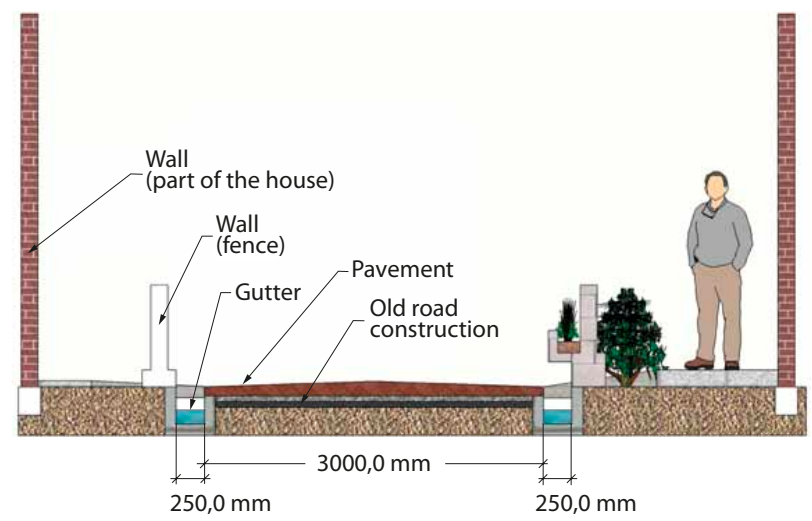

Fig. 4. Section of alley in RT 4 Kampung Karangrejo Sawah (created by the author) 
Green environment, vegetation, and open space

One thing that made Kampung Karangrejo Sawah RT 4 to win in one of the categories in the Green \& Clean program is a lot of maintained vegetation seen along the streets of the kampong. Kampung Karangrejo Sawah RT 4 along with RT 7 wins the category of Floweriest Environment and Best Environmental Management.

Residents volunteered to plant and nurse the flowers in the pots and plants in front of their homes (Fig. 5) and in public areas such as neighbourhood association offices and alley crossings (Figs 7, 8). The existence of large trees sought to be maintained to beautify the kampong. One of the mainstay plants in this kampong is Bougainvillea (Bougainvillea sp.), although there are also encountered other types of plants.

There are a few open spaces found in Kampung Karangrejo Sawah. This is because the houses stand quite close to one another. Open space is found in the form of a field that is in front of the neighbourhood association hall and an open area that is more like a parking lot in front of medical post in RT 4. The field in front of the hall is also used as a parking lot for residents. Both open areas are concrete paved, making it hard for water to penetrate the ground. Other green open space that can be found closest to the kampong is the cemetery in the neighbouring kampong (Fig. 6).

The lack of green space on the side of the road is solved by the residents by voluntarily planting vegetation in the pot and put it along the sideways. This vegetation freshens up the air in this densely populated area with high pollution levels. These benefits can also be improved by incorporating the concept of independent settlements, a settlement that can meet their own needs. By taking advantage of the vegetation in the form of Tabulampot (Fruit Crops in Pots) and hydroponics (growing without soil media), people can generate some of its food (e.g. vegetables and fruits) while keeping the quality of the air in the kampong.
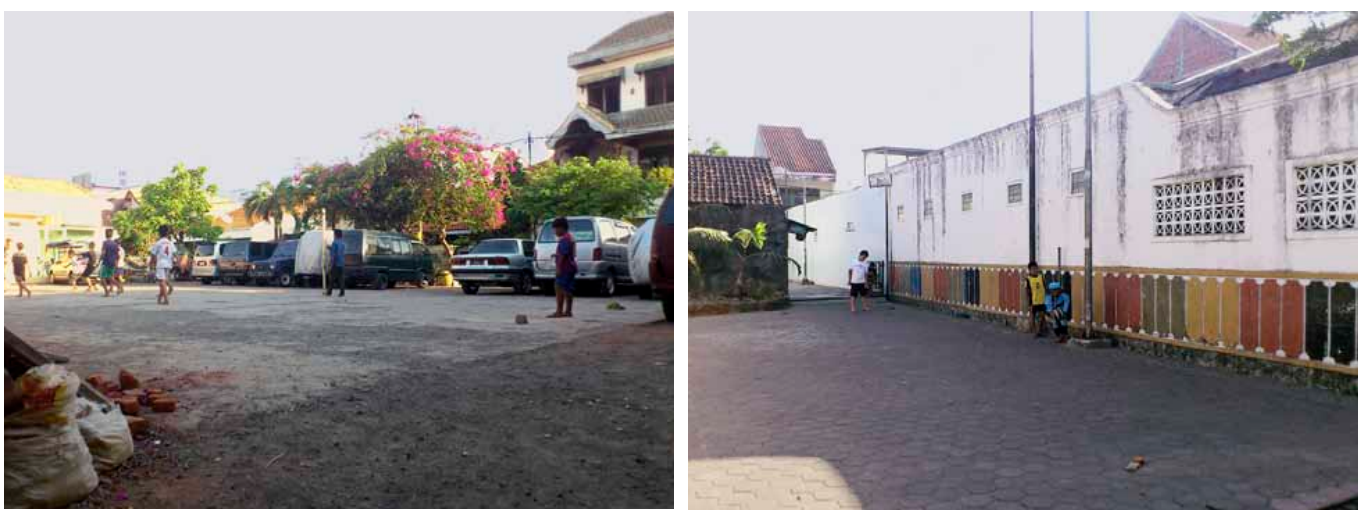

Fig. 7. Left - a field in front of the neighbourhood association hall used as a playground for children and also as a parking lot. Right - a small empty space in front of a medical post in RT 4 (photo by the author)

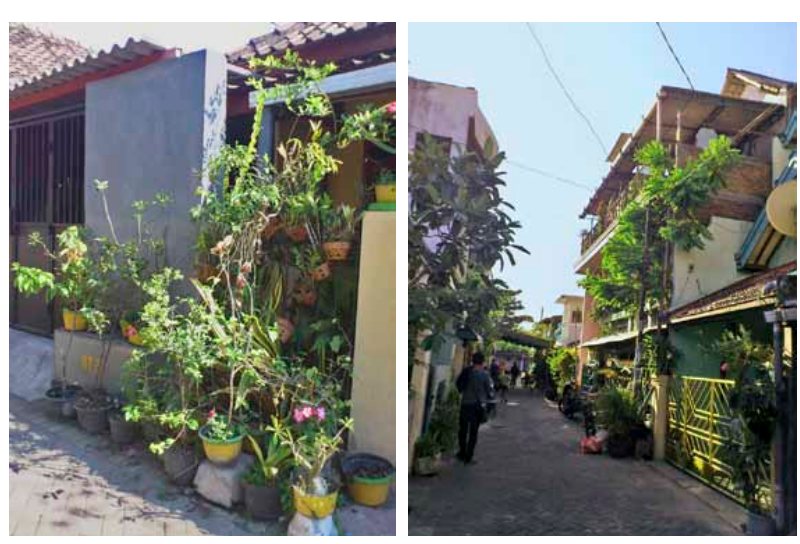

Fig. 5. Flowers planted in the pots independently by local residents (photo by the author)

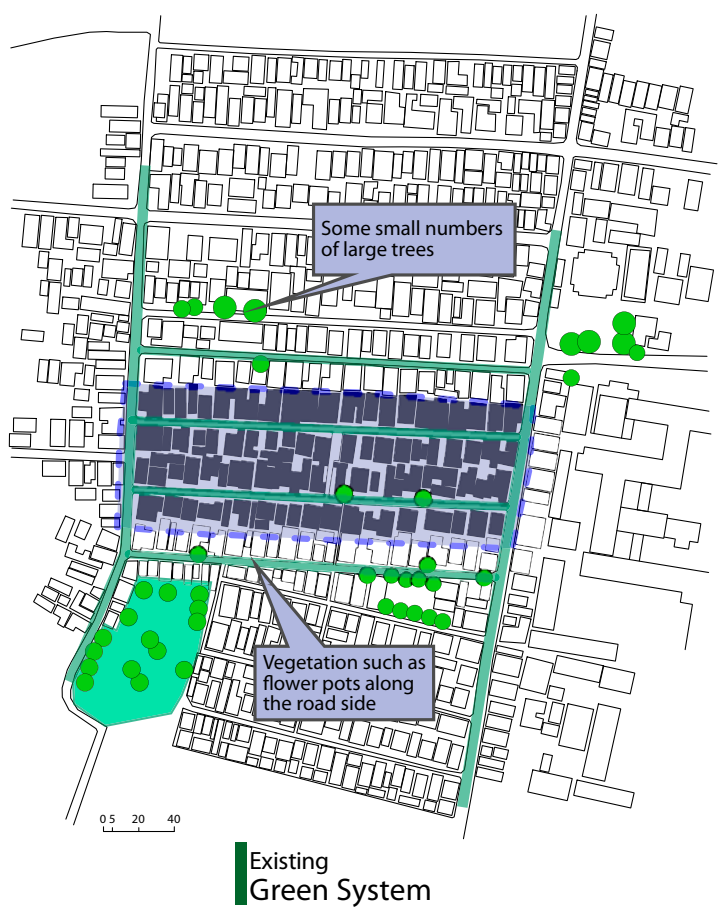

Fig. 6. Distribution of existing vegetation and open space in Kampung Karangrejo Sawah (created by the author) 


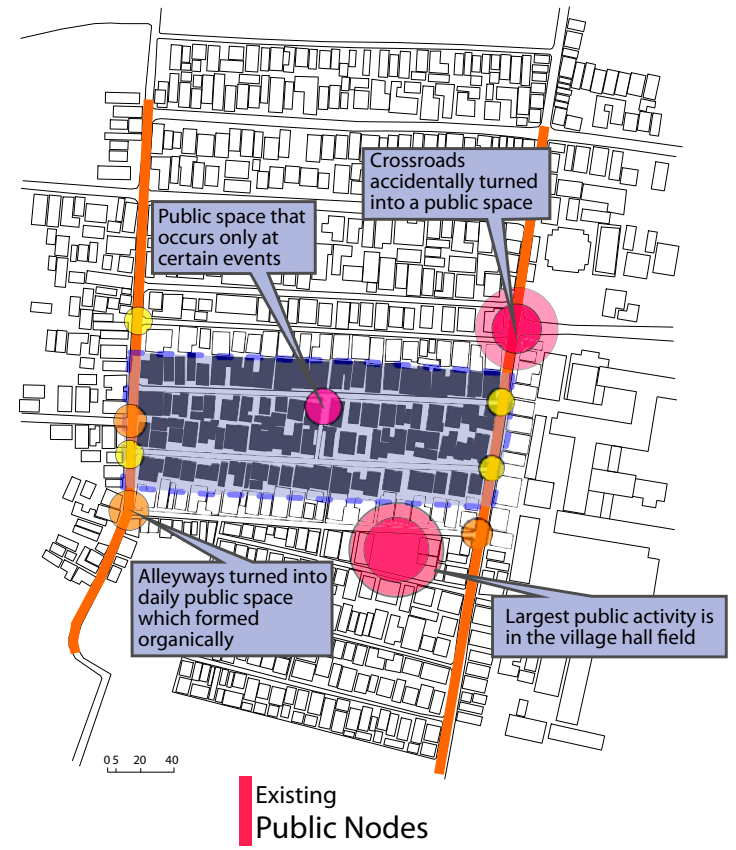

Fig. 8. The layout of the public spaces are formed organically or deliberately in Kampung Karangrejo Sawah (created by the author)

\section{Non-physical sector}

\section{Community internal organization}

The community internal organization has a very important role in society. It can be used as a means to exchange opinions and discussions on issues that cannot be resolved individually. In Kampung Karangrejo Sawah, community organization activities are coordinated by the Chairman of Neighbourhood Association. Activities of these organizations are still limited to overcome some temporary problems, such as security issues, hygiene, and activities of citizens

There are about 130 families in this kampong. However, not all of them own their own home. In one house can be found up to 3 families. The majority of people living in this kampong are the retired citizens living here since the 1960s and local immigrants who are working in the office or shopping centre in nearby downtown. According to the interview of the citizens it is found that there are no many young people in this kampong. Youth Association in this area is no longer active because the most of young people (from second or third generation) have chosen to get out of the kampong.

\section{Kinship in the society}

Even though there are many newcomers (local immigrants) in this community, there are activities to make the indigenous people and newcomers to get closer to each other. Both parties join small scale communal activities in the kampong, such as cleaning up the streets and gutters, the construction of the mosque, hall and public bathroom, or other social activities.

\section{Economic conditions}

The types of business done by the people in this kampong are classified into small individual businesses. Examples of small businesses are food stalls and beverages, grocery stores, and the most common is the boarding house for local immigrants with minimum control from the neighbourhood association. There are no business association or cooperative efforts in this kampong.

\section{Discussion}

Overview of the public space and settlement

Kampong is one of the elements of the city that cannot be overlooked given its local wisdom. Environmental insights in this study are not only focused on how 'green' or how the kampong bears the status, but also on the social engage and mutual cooperation in its community. The needs of green spaces and facilities are increasing; on the contrary the availability of land is decreasing.

According to Pangarsa (2007), the function of a public space is to continue and gather inter-relationships between the core and edge of the spaces that are integrated in a certain arrangement and relationship, to a space that has more plural subject.

The existence of public spaces in Kampung Karangrejo Sawah in District Wonokromo - in the form of alley crossings, circulation/pathway formed organically between houses - is often overlooked by the praxis of planning. The need for a specific space where the people can do their communal activity, such as selling food, children playing care freely, or to have a chat with fellow neighbours, need to be considered. This thought becomes the basic ideas in bringing together the two elements of the city (the kampong and the town) in harmony as a place for activity.

Referring to the statements by Budiharjo (1997), that in order to answer the increasing demands in Indonesian culture, the quality of the resulting space in general should be able to fulfil its function as a place worthy of human activity (liveable), identifiable (imageable), boost productivity, and long-lasting (sustainable), as well as affordable, and can be easily managed. This is where the concept of green development can be incorporated as a bridge to fulfil the function of public space as well as physical effort to produce a green and integrated built environment. 
At Kampung Karangrejo Sawah, public spaces are naturally formed. These activity spaces are narrow alley crossings, junction formed in a narrow corridor between the buildings/houses, or areas shaded by trees. This is where the activities took place from dawn to dusk, even at evenings.

\section{Design criteria}

Based on the conditions and the analysis conducted in previous chapter, several design criteria can be formulated as a guidance for the design concept to bridge the concept of green development with the function of public space. This is intended to produce an integrated green public space beneficial to the kampong and its communal activities while providing a positive physical impact in order to contribute to the Surabaya Green and Clean program.

In Table have been categorized design criteria that will be used combined with the programming method by Duerk (1993) by formulating the mission, goals and performance requirements to create a design concept.

\section{Design concept}

Based on the performance requirements provided in previous chapter, the design concept can be described as this:

- An open space large enough to accommodate many people using the alley and pathways between the buildings.

- Exterior space elements are created by using a flexible bamboo arranged in rows along the alley. The designs are placed at several locations covering the alley crossings, fields, and some roads which become the area of activities for the people (Fig. 9).

- Bamboo is used as the main material with the help of some additional material to place it.

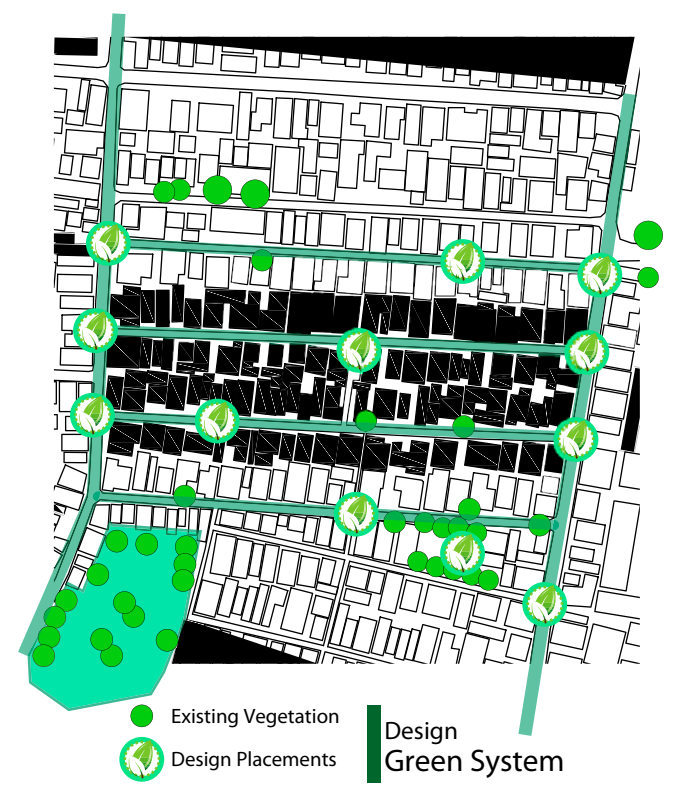

Fig. 9. Suggested placement for the designed object (created by the author)

Figure 10, Figure 11, and Figure 12 show an example of a composite design for the street elements places in alleyways and alley crossings. The slot to put the bamboo is designed with two alternative positions, one is attached to the brick-wall fence and the other is on the narrow runway in between the fence and the gutter. The pipes are placed at a certain distance between $40-60 \mathrm{~cm}$. Citizens can freely install or remove the bamboo according to their needs. The bamboos placed in the pipe slot can be curved and put together to form a sort of tunnel that can be functioned as shading or as a medium to grow plants. The bamboo can also be placed without curved and functioned as a flagpole or banners. Bamboo that has been damaged or is not needed can be removed easily by the homeowner and replaced as needed.

Table. Design criteria for a public space in Kampong

\begin{tabular}{|c|c|c|}
\hline Mission & Goal & Performance Requirement \\
\hline $\begin{array}{l}\text { Public space in a narrow } \\
\text { area ideal for kampong }\end{array}$ & $\begin{array}{l}\text { - Public space to accommodate the } \\
\text { social needs of the community } \\
\text { - Children's playground } \\
\text { - Area for ceremonial/temporary events }\end{array}$ & $\begin{array}{l}\text { - Open space enough to accommodate } \\
\text { many people } \\
\text { - Available seating } \\
\text { - Facilities for children to play }\end{array}$ \\
\hline $\begin{array}{l}\text { Ideal green space for the } \\
\text { community }\end{array}$ & $\begin{array}{l}\text { - Integrated green area in the kampong } \\
\text { - Flexible in a narrow area }\end{array}$ & $\begin{array}{l}\text { - Green area is in an accessible location } \\
\text { - Blends in with surrounding environment } \\
\text { - Can be adjusted in a narrow area } \\
\text { - Does not disturb open space }\end{array}$ \\
\hline $\begin{array}{l}\text { Adaptive public space } \\
\text { inside a kampong }\end{array}$ & $\begin{array}{l}\text { - Its function can be customized } \\
\text { according to various condition }\end{array}$ & $\begin{array}{l}\text { - Public space has an area that is flexible } \\
\text { when it requires a lot of space } \\
\text { - May be reduced for certain activities } \\
\text { - Integrated with green area }\end{array}$ \\
\hline $\begin{array}{l}\text { Exploration in bamboo } \\
\text { material }\end{array}$ & $\begin{array}{l}\text { - The material can adapt with } \\
\text { the public space }\end{array}$ & $\begin{array}{l}\text { - Easy in application and construction } \\
\text { - Does not require complex additional material }\end{array}$ \\
\hline
\end{tabular}




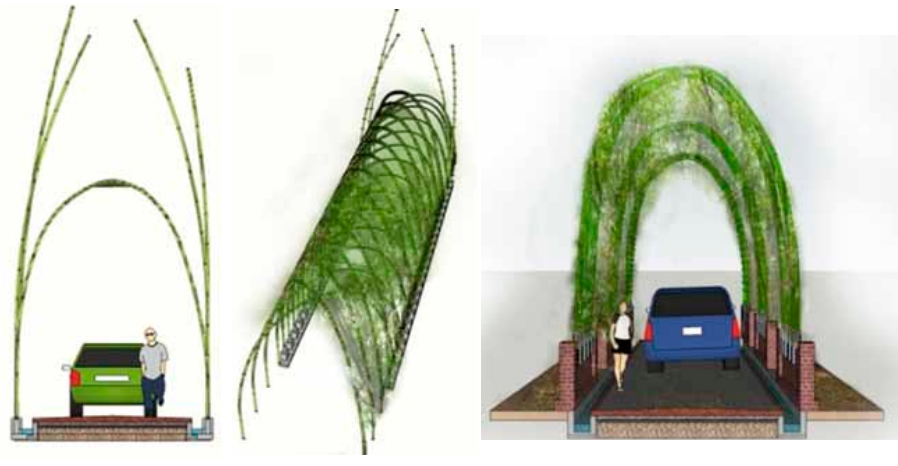

Fig. 10. Designed object placed for alleyways (created by the author)

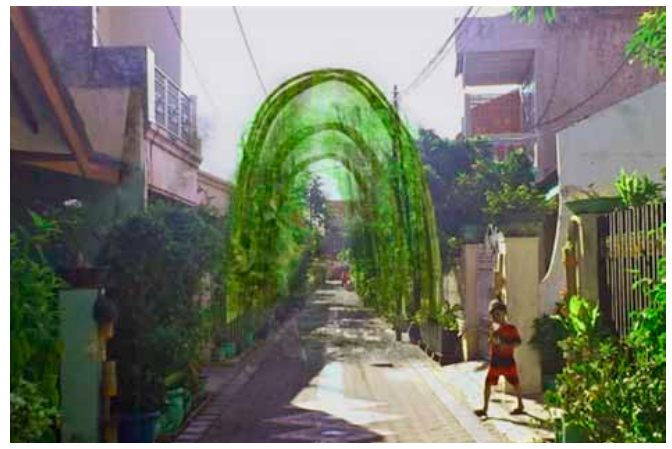

Fig. 11. Rendered image of suggested design for alleyways (created by the author)
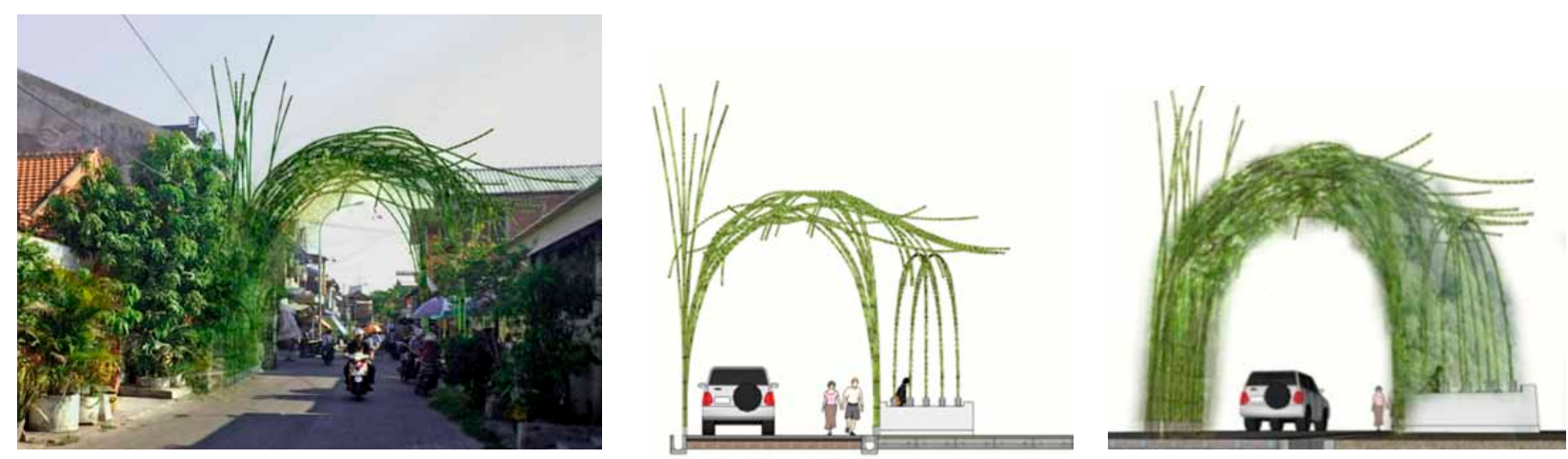

Fig. 12. Rendered image of suggested design for alley crossing (created by the author)

Figure 13 shows an example of a design that is placed on the field in front of the neighbourhood association hall. This design is intended as a shade and fitted with a facility that can be used as a small space for activity or as a complementary field as an additional street/field furniture. The design is made with simple yet robust material, namely bamboo and is made so that it can be used also as a medium to grow plants.

\section{Conclusion}

Problems of limited public space in the kampong can be resolved by applying the principles of adaptive architecture in the alleys or pathways. Public spaces can be adjusted to meet the conditions in this area. One good way is to provide an alternative adaptive design. To achieve this, the use of bamboo becomes the right solution because of its construction, cost, and its properties.

\section{References}

ArchDaily. 2011. Forest Pavilion / nArchitects [online], [cited 06 September 2011]. Available from Internet: http://www. archdaily.com/?p=165393

Basulto, D. 2008. Folded Bamboo + Paper House / Ming Tang [online], [cited 28 October 2008]. Available from Internet: http://www.archdaily.com/?p=8124
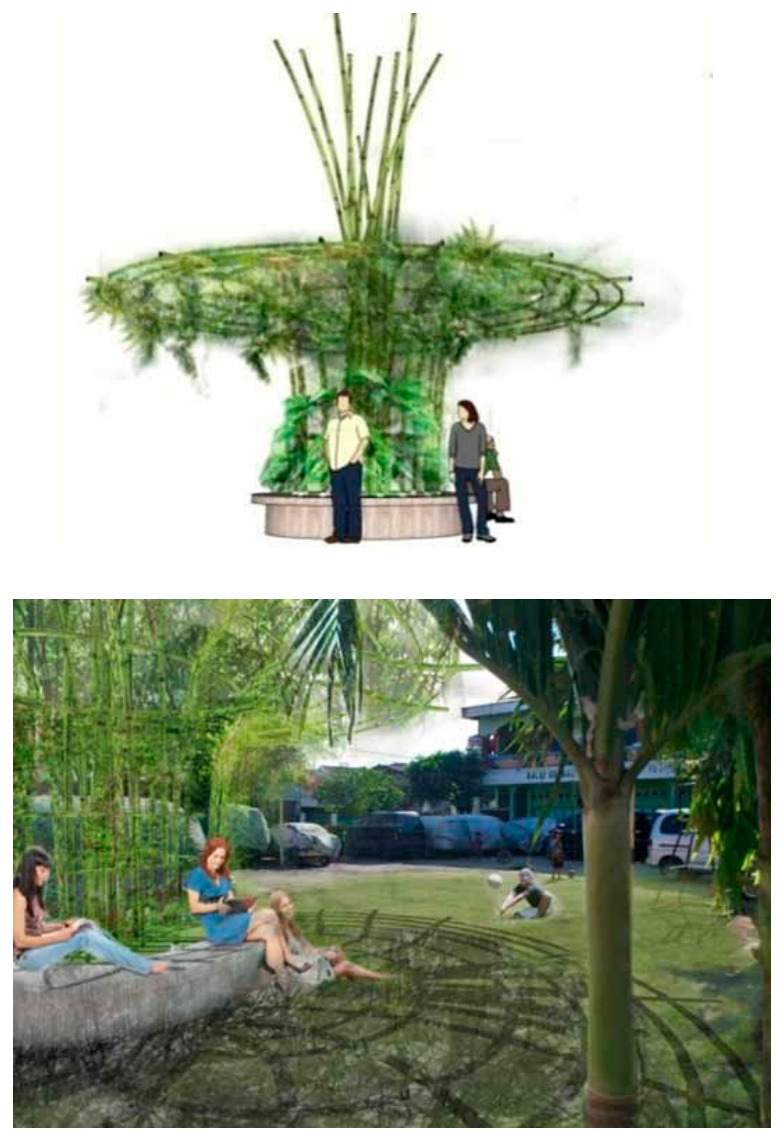

Fig. 13. Rendered image of suggested design on the field (created by the author) 
Budiharjo, E. 1997. Arsitektur sebagai Warisan Budaya. Jakarta: Djambatan.

Carr, S.; Francis, M.; Rivlin, L.; Stone, A. 1992. Public space. Cambridge: Cambridge University Press.

Duerk, D. P. 1993. Architectural programming: information management for design. Canada: John Wiley \&Sons, Inc.

Frearson, A. 2014. Vo Trong Nghia unveils bamboo domes in Vietnam [online], [cited 17 July 2014]. Available from Internet: http://www.dezeen.com/2014/07/17/vo-trongnghia-unveils-new-bamboo-domes-under-construction/

Hijau, T. 2013. Biogas di RW IV Jagir, Ikon Bugenvil di Karangrejo Sawah [online], [cited 8 September 2013]. Available from Internet: http://tunashijau.org/2013/09/03/biogas-di-rw-ivjagir-ikon-bugenvil-di-karangrejo-sawah/

Kronenburg, R. 2007. Flexible: architecture that responds to change. London: Laurence King.

Lynch, K. 1960. The image of the city. Cambridge: MIT Press.

Pangarsa, G. W. 2007. Merah Putih Arsitektur Nusantara. Yogyakarta: Penerbit Andi

Shirvani, H. 1985. The urban design process. New York: Van Nostrand Reinhold.

Undang-Undang Republik Indonesia 1980. Tentang Jalan, Chapter 1 article 1f. (UU No. 13, December 27, 1980). Jakarta: Lembaran Negara Republik Indonesia.

Xiao, Y.; Inoue, M.; Paudel, S. K. 2008. Modern bamboo structures. Leiden: CRC Press.

\section{SUKMO D. WIDHARTO}

Institut Teknologi Sepuluh Nopember, Surabaya, East Java, Indonesia.E-mail: sukmoduto@gmail.com

Sukmo Widharto is a postgraduate student of architecture in Institut Teknologi Sepuluh Nopember in Surabaya, Indonesia and a graduate of Brawijaya University. His current research interests involve facade system and renewable energy for buildings. He is also a practitioner in architecture and this is his first international journal publication.

\section{NURFAHMI MUCHLIS}

Institut Teknologi Sepuluh Nopember, Surabaya, East Java, Indonesia.E-mail:fahmi.muchlis@gmail.com

Nurfahmi Muchlis is a lecturer and a graduate of architecture in Institut Teknologi Sepuluh Nopember in Surabaya. His latest research involve around parametric architecture and its application in ethnic building. His current research interest involve in algorithmic and parametric architecture.

\section{SIGIT H. LAKSONO}

Institut Teknologi Sepuluh Nopember, Surabaya, East Java, Indonesia.E-mail: sigitarchi@yahoo.com

Sigit Laksono is a graduate of architecture in Institut Teknologi Sepuluh Nopember in Surabaya. His latest research involve ecotourism desing in riverbanks. He is now practicing architecture in Surabaya.

\section{PURWANITA SETIJANTI}

Institut Teknologi Sepuluh Nopember, Surabaya, East Java, Indonesia.E-mail: psetijanti@arch.its.ac.id
Purwanita Setijanti is a lecturer in Institut Teknologi Sepuluh Nopember in Surabaya. A graduate of University of Melbourne and Institut Teknologi Sepuluh Nopember, she has written one book and over 15 articles in professional journals. She also received an award of Dwidya Satya Perdana from where she taught. Her current research interest involve housing, human settlements and urban design/planning. 